\title{
Clinico-morphological characteristics of patients with systemic scleroderma before and after autologous bone marrow-derived mesenchymal stem cells transplantation
}

Natalya Krivoruchko', Aigerim Imanberdiyeva', Manarbek Askarov², Galina Fedotovskikh ${ }^{3}$, Galiya Shaimardanova ${ }^{4}$, Saltanat Tuganbekova ${ }^{1}$

${ }^{1}$ No 4 Therapy Department, National Scientific Medical Center, Astana, Republic of Kazakhstan

${ }^{2}$ Cellular Technologies and Transplantation Center, National Scientific Medical Center, Astana, Republic of Kazakhstan

${ }^{3}$ Scientific and Research Laboratory, National Scientific Medical Center, Astana, Republic of Kazakhstan

${ }^{4}$ Scientific Research Management Department, National Scientific Medical Center, Astana, Republic of Kazakhstan

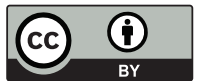

This work is licensed under a Creative Commons Attribution 4.0

Received: 2018-03-15

Accepted: 2018-10-09

UDC: 616

\section{J Clin Med Kaz 2018;3(49):50-54}

Corresponding Author: Aigerim Imanberdiyeva, "National Scientific Medical Center" JSC. Address: 42, Abylai Khan avenue, 000001, Astana, Republic of Kazakhstan. Tel.: +7 7023414585

E-mail: aika-im@mail.ru

\section{Abstract}

The article describes the clinical and morphological dynamics of systemic scleroderma diffuse form on the background of autologous bone marrow mesenchymal stem cells transplantation. The basis for the mesenchymal stem cells transplantation was the presence of a high activity index of the autoimmune process (EScSG), expressed diffuse skin changes (dense edema, induration) and resistance to immunosuppressive therapy. Transplantation of autologous bone marrow cells at systemic scleroderma contributes clinically to a significant reduction or cupping of skin induration, Raynaud's syndrome, improvement of patient's quality of life; morphological decrease of excessive fibrous tissue, stimulation of angiogenesis, and restoration of skin epithelium.

Keywords: systemic scleroderma, fibrosis, skin flap, mesenchymal stem cells, bone marrow transplantation

\section{ЖУЙЕЛІ СКЛЕРОДЕРМИЯМЕН АУЫРАТЫН НАУҚАСТАРДЫН АУТОЛОГИЯЛЫҚ МЕЗЕНХИМАЛДІ СУЙЕК КЕМІГІНІҢ ТРАНСПЛАНТАЦИЯСЫНА ДЕЙІНГІ ЖӘНЕ КЕЙНГІ КЛИНИКАЛЫК-МОРФОЛОГИЯЛЫК СИПАТТА- МАСЫ}

Криворучко Н.А. ${ }^{1}$, Иманбердиева А.М. ${ }^{1}$, Асқаров М.Б. ${ }^{2}$, Федотовских Г.В.3, Шаймарданова Г.М. ${ }^{4}$, Туганбекова С.К. ${ }^{1}$

№4 терапия бөлімшесі, Ұлттық ғылыми медициналық орталық, Астана, Қазақстан Республикасы

²асушалық технология және трансплантаттау орталығы, Ұлттық ғылыми медициналық орталық, Астана, Қазақстан Республикасы

${ }^{3}$ Ғылыми-зерттеу зертханасы, Ұлттық ғылыми медициналық орталық, Астана, Қазақстан Республикасы

${ }^{4}$ Ғылыми зерттеулер менеджменті бөлімі, Ұлттық ғылыми медициналық орталық, Астана, Қазақстан Республикасы

\section{т¥ЖЫРЫмдАмА}

Мақалада аутологиялық сүйек кемігінің мезенхимальдік бағаналы жасушаларын трансплантациялау аясында жүйелі склеродермияның диффузды түрінің клиникалық және морфологиялық динамикасы сипатталған. Мезенхимальді бағаналы жасушаларды трансплантациялауға негіз-аутоиммунды үрдістің белсенділігінің жоғары активті индексінің жоғары болуы (EScSG), тері өзгерістерінің анықталуы (тығыз ісіну, индюрация) және иммуносупрессивті терапияға төзімділігі болды. Жүйелі склеродермия кезінде аутологиялық сүйек кемігінің жасушаларын трансплантациялау клиникалық тұрғыдан тері индурациясының, Рейно синдромының айтарлықтай жақсаруына немесе толықтай жазылуына, науқастың өмір сапасын жақсартуға; морфологиялық тұрғыдан талшықты дәнекер тінінің шамадан тыс бөлініун азайтуға, ангиогенезді ынталандыруға және тері эпителийін қалпына келтіруге айтарлықтай ықпал етеді.

Негізгі сөздер: жүйелі склеродермия, фиброз, тері жамылғысы, мезенхимальді сүйек кемігі, сүйек кемігін трансплантациялау 


\section{КЛИНИКО-МОРФОЛОГИЧЕСКАЯ ХАРАКТЕРИСТИКА БОЛЬНЫХ ДО И ПОСЛЕ ТРАНСПЛАНТАЦИИ АУТОЛО- ГИЧНЫХ МЕЗЕНХИМАЛЬНЫХ СТВОЛОВЫХ КЛЕТОК КОСТНОГО МОЗГА ПРИ СИСТЕМНОЙ СКЛЕРОДЕРМИИ}

Криворучко Н.А. ${ }^{1}$, Иманбердиева А.М. ${ }^{1}$, Аскаров М.Б. ${ }^{2}$, Федотовских Г.В. ${ }^{3}$, Шаймарданова Г.М. ${ }^{4}$, Туганбекова С.К. ${ }^{1}$

'Отделение терапии №4, Национальный научный медицинский центр, Астана, Республика Казахстан

${ }^{2}$ Центр клеточных технологий и трансплантации, Национальный научный медицинский центр, Астана, Республика Казахстан

${ }^{3}$ Научно-исследовательская лаборатория, Национальный научный медицинский центр, Астана, Республика Казахстан

${ }^{4}$ Отдел менеджмента научных исследований, Национальный научный медицинский центр, Астана, Республика Казахстан

\section{PEЗЮME}

В статье описана клинико-морфологическая динамика диффузной формы системной склеродермии на фоне трансплантации мезенхимальных стволовых клеток аутологичного костного мозга. Основанием для проведения трансплантации мезенхимальных стволовых клеток послужило наличие высокого индекса активности аутоиммунного процесса (EScSG), выраженные диффузные изменения кожи (плотный отек, индурация) и резистентность к иммуносупрессивной терапии. Трансплантация аутологичных клеток костного мозга при системной склеродермии способствует клинически значительному уменьшению или купированию индурации кожи, синдрома Рейно, улучшению качества жизни пациента, морфологическому уменьшению избыточной фиброзной ткани, стимуляции ангиогенеза и восстановлению эпителия кожи мозга

Ключевые слова: системная склеродермия, фриброз, кожный лоскут, мезенхимальные стволовые клетки, трансплантация костного

\section{Введение}

Аутоимму́нные заболева́ния (от аv̉ он самый») — это класс разнородных по клиническим проявлениям заболеваний, развивающихся вследствие патологической выработки аутоиммунных антител или размножения аутоагрессивных клонов киллерных клеток против здоровых, нормальных тканей организма, приводящих к повреждению и разрушению нормальных тканей и к развитию аутоиммунного воспаления. Аутоиммунные заболевания вызваны нарушением функции иммунной системы в целом или её отдельных компонентов. [1].

По сути своей, аутоиммунные заболевания представляют собой определенные состояния, которые возникают в результате иммунологической реакции организма, направленной против тканей собственного тела. Иными словами, иммунная система ошибочно принимает собственные клетки за антигены. Аутоиммунные заболевания являются крайне опасным явлением, так как они способны разрушать ткани организма, вызывать аномальный рост различных органов, или просто нарушать функционирование этих органов.

В этой связи большое практическое значение приобретает проблема «контроля над болезнью». По современным представлениям, в основе аутоиммунных заболеваний лежат сложные процессы, связанные с нарушением селекции Т- и В-клеток, приводящие к «патологическому» иммунному ответу против собственных тканей (аутоантигенов) [2].

Системнаясклеродермия(ССД)-системноезаболевание соединительной ткани, характеризующееся воспалением и прогрессирующим фиброзом кожи и поражением всех внутренних органов. В основе патогенеза данного заболевания лежит нарушение процесса взаимодействия различных клеток (эндотелиальные и гладкомышечные клетки сосудистой стенки, фибробласты, Т и В лимфоциты, моноциты, макрофаги, тучные клетки, эозинофиты) друг с другом и с компонентами соединительнотканного матрикса. Развитие сосудистой патологии происходит по типу облитерирующей микроантгиопатии, что приводит к развитию ишемических процессов [3].

Основной признак системной склеродермииуплотнение кожи, развивающееся вследствие патологической выработки коллагена I типа фибробластами кожи, а также избыточных отложений гликозаминогликанов и фибронектина во внеклеточном матриксе. В очагах уплотнения кожи атрофируются потовые железы и выпадают волосы.

Частота ССД составляет 2,7-12 человек на 1 млн населения, причем в последние десятилетия отмечается рост заболеваемости, женщины болеют в 3-4 раза чаще мужчин (3:1); заболевание начинается в возрасте 20-40 лет, возможны варианты после 60 лет.

\section{Цель исследования}

Оценить клинико-морфологическое состояние кожи больных системной склеродермией до и после трансплантации аутологичных мезенхимальных стволовых клеток костного мозга.

\section{Материалы и методы исследования}

Критериями включения в исследуемую группу являлись:

1. наличие достоверного диагноза системная склеродермия (диффузная форма), согласно критериям Американской коллегии ревматологов, в возрасте от 18 до 60 лет включительно;

2. стадии аутоиммунного процесса $1,2,3$;

3. активность аутоиммунного процесса $0,1,2$ степени;

4. отсутствие эффекта ранее проводимой базисной иммуносупрессивной терапии;

5. исследуемый подписывал письменное информированное согласие, согласно рекомендациям Good Clinical Practic (GCP).

Под нашим наблюдением находилось 23 пациента с достоверным диагнозом ССД, диффузная форма, которые были разбиты на 2 группы: основная (с проведением трансплантации мезенхимальных стволовых клеток аутологичного костного мозга) -13 человек, контрольная группа - 10 человек. Обе группы сопоставимы по возрасту, полу (все женщины). Длительность заболевания составляла в среднем более 5 лет.

Основанием для проведения трансплантации мезенхимальных стволовых клеток послужило наличие высокого индекса активности аутоиммунного процесса (EScSG), выраженные диффузные изменения кожи (плотный 
отек, индурация) и резистентность к иммуносупрессивной терапии. Схема визитов в группах исследования через 0-36-9-12 месяцев после трансплантации мезенхимальных стволовых клеток костного мозга. Для оценки степени активности патологического процесса определяли показатели периферической крови, уровень С-реактивного белка, ANA, ENA.

Оценка эффективности проводилась по данным лабораторного исследования- CD3, CD4, CD8, CD20, CD16, CD4+CD25+Foxp3, CD38, Ил-1 $\beta$, Ил-4, Ил-10, Ил-6, ФНО- $\alpha$, ANA, TGFa, комплемент C3,C4, и клиническим - уровень оценки кожного счета по методу Роднана, морфологического исследования - биопсия кожного лоскута.

Материалом для морфологического исследования послужил биопсийный материал кожи голени в стадии индурации, взятый до и после трансплантации ММСК. Гистологические парафиновые срезы окрашивались гематоксилином и эозином и гистохимически по Массон - трихром. Для электронной микроскопии материал проводили по общепринятой методике и заключали в эпон. Исследование проводили на электронном микроскопе Libra 120 фирмы Carl Zeiss.

Проведение операции миелотрансплантации мезенхимальных стволовых клеток аутологичного костного мозга (ММСК) осуществлялась в два этапа:

1. Миелоэкфузия изподвздошной кости ибиотехнология мезенхимальной фракции стволовых клеток. Проводилась аспирация костного мозга из гребня подвздошной кости в количестве 400 мл, биотехнологическим методом выделяется мезенхимальная фракция стволовых клеток с последующим культивированием их в течение 4-х недель.

2. Трансплантация мезенхимальных стволовых клеток проводилась системно (внутривенно) в среднем в количестве до 140×106 клеток, осуществляется со скоростью 50 мл/ч. Время трансфузии составляет 3 часа.

\section{Результаты.} $\pm 10,11$.

Средний возраст исследуемых при ССД составил 43,0

Проводилась оценка активности аутоиммунного процесса согласно шкале активности ССД по EScSG, Роднана, а также мофрологическая оценка кожного лоскута при ССД до и после трансплантации аутологичных стволовых клеток костного мозга. У всех пациентов ССД была диффузная форма поражения. Согласно шкале активности по EScSG, данный показатель в обеих группах составил 3,2 балла.

Отмечается выраженный клинический эффект в основной группе после проведения миелотрансплантации мезенхимальных стволовых клеток (ММСК) при ССДзначительно уменьшается индурация кожи, дисфагия, купируются мышечные контрактуры, уменьшаются приступы вазоспазма (синдром Рейно), отмечено достоверное снижение плотности кожи $(\mathrm{p}<0,03)$ - кожный счет по Роднану, динамика КС отражена в Таблице №1.

Таблица 1 Динамика кожного счета (КС) по Роднану до и после ММСК (основная группа)

\begin{tabular}{|l|l|l|}
\hline до ММСК & после ММСК через 3 месяца & $\begin{array}{l}\text { после ММСК через } 6 \\
\text { месяцев }\end{array}$ \\
\hline $21,13 \pm 2,52$ & $14,79 \pm 2,38$ & $10,83 \pm 1,57$ \\
\hline
\end{tabular}

$\mathrm{P}<0,03$
В сравнении с контрольной группой-исходная 19,46 \pm 2,42 , через 3 месяца $18,45 \pm 2,27$, через 6 месяцев $19,15 \pm$ 2,05 .

Клинически уже через три месяца наблюдения у больных ССД после трансплантации аутологичных стволовых клеток отмечено достоверное уменьшение активности по EScSG с 3,21 до 2,48 баллов, через 6 месяцев с 3,21 до 1,58 бал, в контрольной же группе отмечалась тенденция к снижению данного показателя с 3,2 до 2,4 балла.

Проводилась лабораторная оценка эффективности ММСК путем определения маркеров дифференцировки лимфоцитов методом проточной цитофлуорометрии (CD3, CD4, CD8, CD16, CD19, CD20, CD38), цитокинов (ИЛ1, ИЛ-4, ИЛ-6, ИЛ-10, TNF $\alpha$, IFN $\gamma$ ) иммуноферментным методом, наличия специфических аутоантител (ANA, ENA) на анализаторе ChemWell, USA.

После второй процедуры (через 3 месяца) ММСК зарегистрировано значимое уменьшение экспрессии иммунокомпетентных клеток CD3, CD4, CD8, CD16, CD19, $\mathrm{CD} 20$ ( $<<0,05)$, Была отмечена нормализация цитокинового профиля со снижением провоспалительных цитокинов: ИЛ1, ИЛ-6, ИЛ-8, ТNF $\alpha$, IFN $\gamma(\mathrm{p}<0,05)$.

Проведенный сравнительный анализ показателей иммунной системы отметил достоверное снижение ANA $(\mathrm{t}=2,71 ; \mathrm{p}<0,05)$ и ENA $(\mathrm{t}=3,39 ; \mathrm{p}<0,05)$ у больных ССД в основной группе по сравнению с контрольной, что говорит об эффективности ММСК и о повышении иммунного статуса больных ССД после введения стволовых клеток костного мозга.

Достоверное снижение СОЭ по данным 3 трансплантаций (согласно протоколу до, через 3, 6 мес.) составило соответственно: $25,44 \pm 1,86,20,54 \pm 1,56,21,04$ $\pm 2,42, \quad(\mathrm{p}<0,05)$, достоверное снижение СРБ составило соответственно: 7,04 $\pm 1,63,3,39 \pm 1,70,2,43 \pm 2,10,(\mathrm{p}<0,05)$. У пациентов с ССД в контрольной группе (без проведения ММСК, но получали базисную иммуносупрессивную терапию) зарегистрированы более высокие показатели СОЭ $(23,01 \pm 1,68$ мм/ч) и КС $(19,46 \pm 2,05$ баллов), СРБ$7,11 \pm 1,73,6,54 \pm 2,17,6,18 \pm 1,57$, чем в исследуемой группе, где пациенты получали ТМСК.

После проведения трансплантации аутологичных стволовых клеток (ММСК) у больных системной склеродермией установлен частичный или полный ответ у $92 \%$ случаев, в виде уменьшения кожного счета, улучшения микроциркуляции, что подтверждено морфологическим исследованием.

Светооптическое исследование кожи больных ССД до лечения показало атрофию эпидермиса, фиброзирование соединительной ткани дермы, патологию сосудов микроциркуляторного русла. Резкое истончение эпидермиса приводило к разрывам и полной десквамации эпителиальных слоев, особенно на участках с выраженным подэпителиальным фиброзом. На полутонких срезах наблюдалась яркая фуксинофилия плотно упакованных волокон папиллярного слоя (Рисунок 1).

При гистохимическом исследовании соединительная ткань дермы окрашивалась по Массон - трихром в интенсивно синий цвет. Электронномикроскопически коллагеновые волокна были представлены полями неупорядоченно расположенных пучков коллагеновых фибрилл неравномерной толщины и оптической плотности с деградацией в форме отека, разрыхления, зернистого и

Journal of Clinical Medicine of Kazakhstan: Volume 3, Number 49, Issue 2018 
аморфного распада. Просматривались и патологические формы коллагена в виде поперечно-связанных микрофибриллярных агрегатов.

Микроциркуляторная сеть кровеносных капилляров дермы на светооптическом уровне была изменена и имела полиморфное строение. Наблюдались капилляры как с гипертрофированными эндотелиальными клетками и пролиферирующими перицитами, так и облитерированные сосуды с гомогенизированной темной или светлой некротизированной выстилкой. В папиллярном слое некроз эндотелия коротких капилляров, «замурованных» плотной фиброзной тканью. В глубоких слоях дермы облитерированные сосуды выстланы патологически

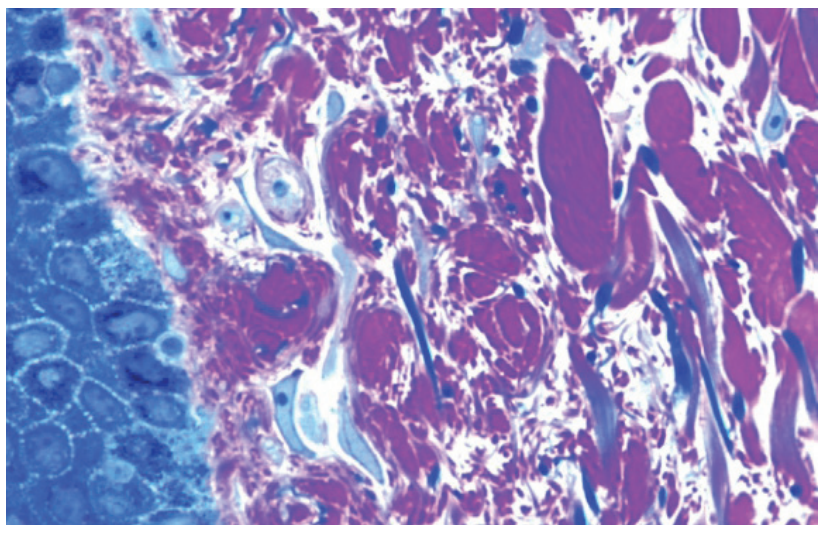

Рисунок 1 - Морфология кожи при системной склеродермии до трансплантации клеток костного мозга. Плотная соединительная ткань папиллярного слоя.

Полутонкий срез. Окраска метиленовым синим, азуром 2 и основным фуксином. Ув.х200

Инфильтраты из лимфоцитов, фибробластоподобных и тучных клеток располагались в периваскулярной области. Здесь же были выявлены крупные продолговатой формы фибробласты без отростков, с признаками высокой синтетической активности и наличием в цитоплазме многочисленных диктиосом комплекса Гольджи, хорошо развитых канальцев гранулярного эндоплазматического ретикулума с хлопьевидным материалом в просвете (Рисунок 3).

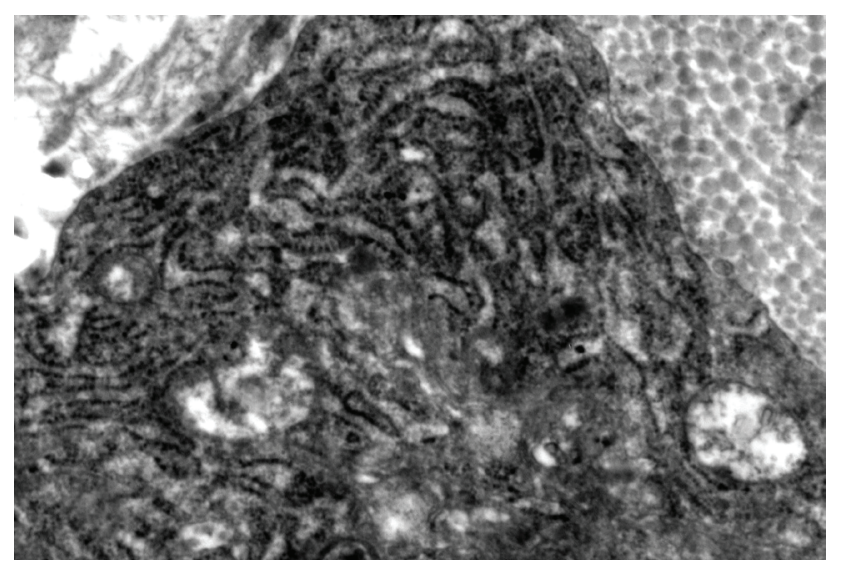

Рисунок 3 - Морфология кожи при системной склеродермии до трансплантации клеток костного мозга. Активированный фибробласт с многочисленными ГЭР и комплексом Гольджи. Электроннограмма.

Увеличениех9000 измененными темными клетками с редуплицированной, разрыхленной и фрагментированной базальной мембраной. Эндотелий сохранных капилляров окружен гипертрофированными перицитами. Наблюдались признаки апоптоза и полной деструкции эндотелиальных клеток

В дерме клеточная инфильтрация зависела от степени фиброзирования соединительной ткани и сохранности кровеносных капилляров. В области активного фибриллогенеза она была выше, чем в плотной склерозированной и гиалинизированной ткани. Основными клеточными элементами кроме недифференцированных клеток и фиброцитов были миофибробласты (МФБ) с характерными филаментами (Рисунок 2).

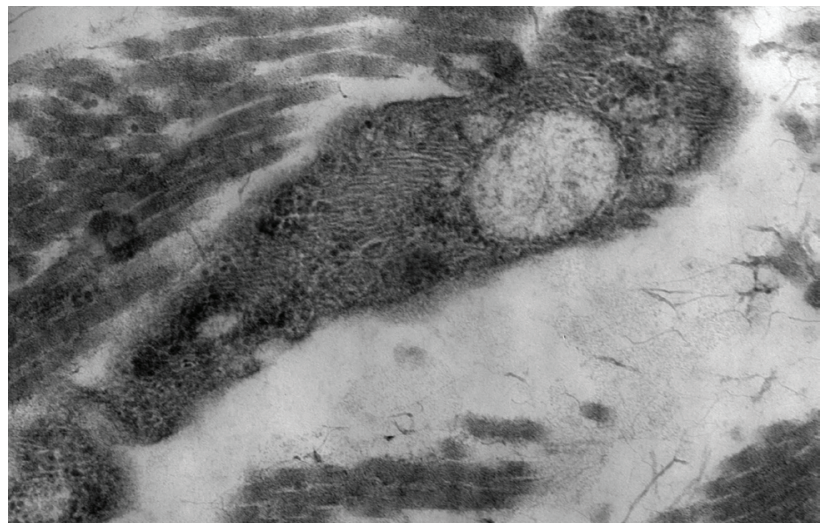

Рисунок 2 - Морфология кожи при системной склеродермии до трансплантации клеток костного мозга. Миофибробласт соединительной ткани с миофиламентами и набухшими митохондриями. Электроннограмма.

Увеличение х13000.

Через три месяца после трансплантации стволовых клеток при светооптическом исследовании кожи наблюдалось значительное уменьшение интенсивности окрашивания фиброзной ткани при гистохимическом исследовании, которая характеризует снижение отложения соединительной ткани. На полутонких срезах на отдельных участках хорошо было видно уменьшение плотности пучков фиброзных волокон с расщеплением их на фрагменты и отдельные волокна (Рисунок 2а). Уменьшалось число фибробластов. Вокруг полей новообразованных сосудов отмечено наиболее выраженное разрежение фиброзной ткани. В клеточном составе приваскулярной локализации появлялись многочисленные макрофаги с крупными вакуолями. В базальном слое эпидермиса наблюдались многочисленные крупные вакуоли.

Электронномикроскопически в дерме были отмечены фиброциты, а также фибробласты с признаками пониженной белковой функции: светлыми расширенными и вакуолизированными канальцами ГЭР и деструктивно измененными митохондриями (Рисунок 2б). Фибробласты с плотно прилежащими коллагеновыми фибриллами были представлены разрушенной плазматической мембраной и содержали вакуолизированные канальцы ГЭР и митохондрии. Многие фибробласты с многочисленными вторичными лизосомами подвергались деструкции. 


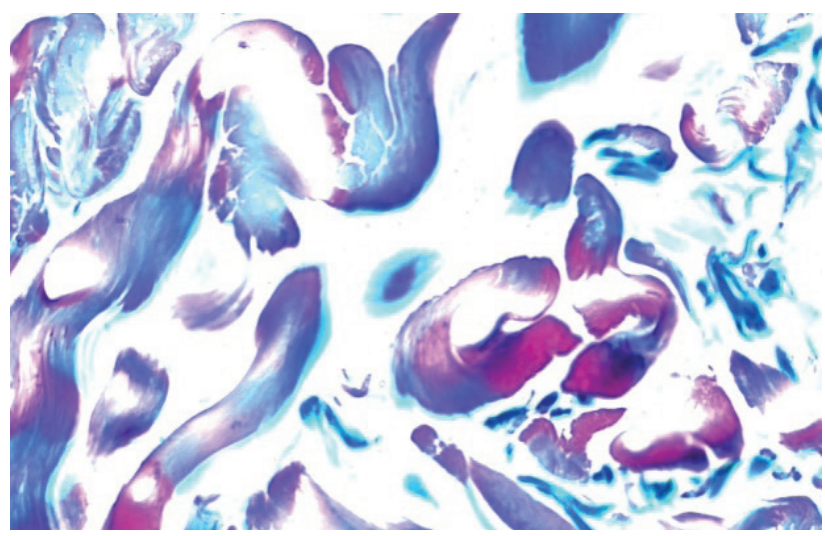

Рисунок 2а. - Морфологическая картина кожи при системной склеродермии после трансплантации стволовых клеток костного мозга.

a - снижение плотности расположения пучков коллагена с распадом их на фрагменты. Полутонкий срез. Окраска метиленовым синим, азуром 2 и основным фуксином (x1000);

\section{Обсуждение}

Ужечерезтримесяцапослепроведения трансплантации стволовых клеток костного мозга наблюдалась положительная динамика морфофункционального состояния кожи больных системной склеродермией. Отмечается выраженный клинический эффект в основной группе - значительно уменьшается индурация кожи, дисфагия, купируются мышечные контрактуры, отмечено достоверное снижение плотности кожи $(\mathrm{p}<0,03)$ - кожный счет по Роднану.

Результаты проведенных клинических и морфологических исследований позволят обосновать принципиальную возможность использования клеточной трансплантации при лечении аутоиммунных заболеваний, в частности при диффузной форме системной склеродермии. Использование мезенхимальных стволовых клеток костного мозга, которым присущи иммуномодулирующие (естественная супрессорная активность), морфо - и ангиогенетические, а также антифибротические эффекты может стать эффективным и патогенетически оправданным методом лечения системной склеродермии [4].

Изучение специфических и неспецифических механизмов действия, а также исследование ранних и отдаленных последствий трансплантаций стволовых клеток костного мозга, позволяет приблизиться к широкому

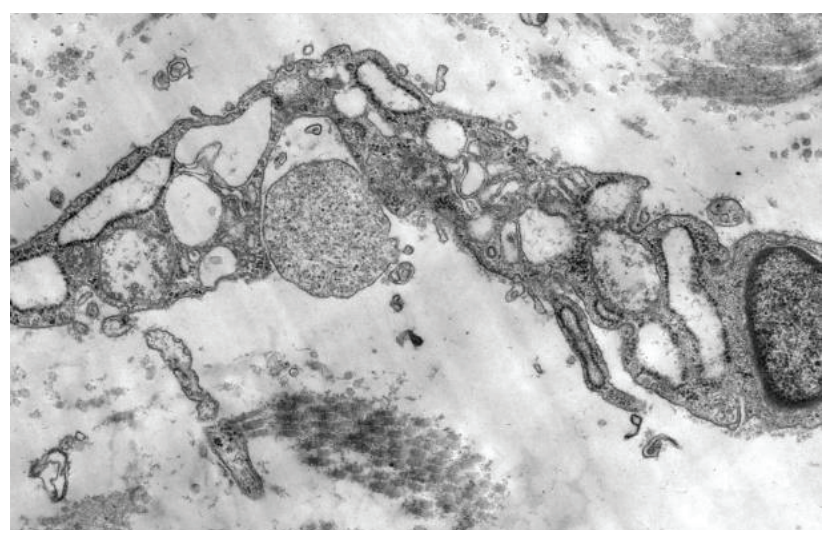

Рисунок 2б. - Морфологическая картина кожи при системной склеродермии после трансплантации стволовых клеток костного мозга.

б-фибробласт с крупными вакуолизированными канальцами ГЭР и митохондриями. Электроннограмма. (x4000).

применению данного метода в клинической практике.

Предлагаемая в качестве комбинированного лечения трансплантация мезенхимальных клеток аутологичного костного мозга может существенно улучшить качество жизни данной категории больных, наряду со снижением при этом дозы вводимых извне иммуносупрессивных препаратов.

\section{Выводы}

Трансплантация аутологичных стволовых клеток костного мозга, представляя новый терапевтический подход лечения ССД, включала ауторегуляторные механизмы уменьшения избыточной соединительной ткани, стимуляцию ангиогенеза и восстановление эпителия и придатков кожи больных ССД.

Все это диктует необходимость дальнейшего изучения лечения ССД с применением, наряду с традиционной иммуносупрессивной терапией, трансплантации мезенхимальных стволовых клеток аутологичного костного мозга.

Disclosures: There is no conflict of interest for all authors.

\section{Список литературы}

1. Steen VD, Medsger Jr TA. Severe organ involvement in systemic sclerosis with diffuse scleroderma. Arthritis \& Rheumatism. 2000;43(11):2437-44.

2. Davidson A, Diamond B. Autoimmune diseases. New England Journal of Medicine. 2001;345(5):340-50.

3. Gusseva N.G. Sistemnaya sclerodermiya - multidistsiplinarnaya problema (Systemic scleroderma - multidisciplinary problem) [in Russian]. Zhurnal nauchno-prakticheskaya revmatologiya. 2011; 2:10-14.

4. Santiago B, Galindo M, Rivero M, Pablos JL. Decreased susceptibility to Fas-induced apoptosis of systemic sclerosis dermal fibroblasts. Arthritis \& Rheumatism. 2001;44(7):1667-76.

How to cite this article: Natalya Krivoruchko, Aigerim Imanberdiyeva, Manarbek Askarov, Galina Fedotovskikh, Galiya Shaimardanova, Saltanat Tuganbekova. Clinico-morphological characteristics of patients with systemic scleroderma before and after autologous bone marrow-derived mesenchymal stem cells transplantation [in Russian]. J Clin Med Kaz. 2018; 3(49):50-54 